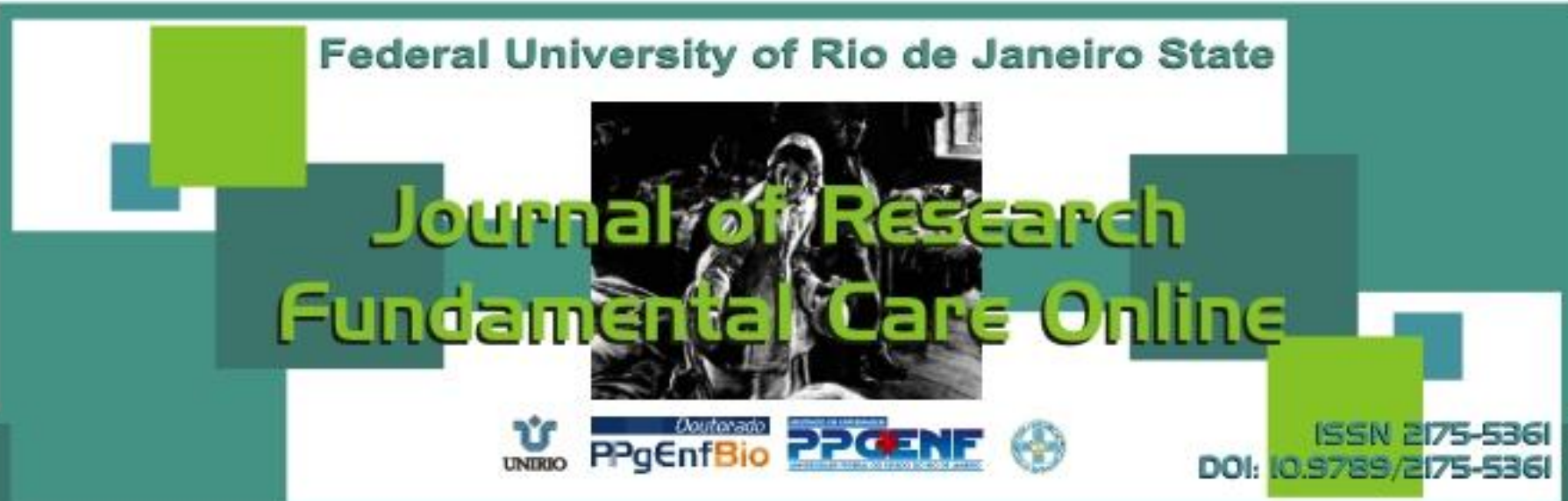

\title{
RESEARCH
}

\section{Knowledge of health professionals about the distribution of pasteurized human milk}

Conhecimento de profissionais de saúde acerca da distribuição do leite humano pasteurizado

Conocimiento de profesionales de la salud acerca de la distribución de la leche materna pasteurizada

Rosineide Santana de Brito ${ }^{1}$, Talita Cavalcante de Araújo Mello ${ }^{2}$, Danyelle Leonette Araújo dos Santos $^{3}$, Aline Ribeiro de Lima ${ }^{4}$, Edualeide Jeane Pereira Bulhões da Nóbrega ${ }^{5}$

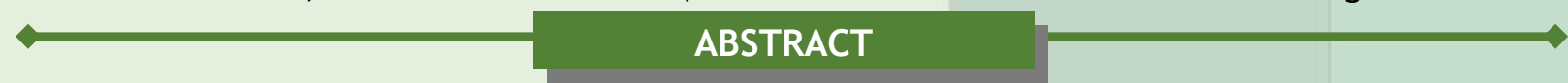

Objective: To verify the knowledge of the health team who works in Neonatal Intensive Care Unit and / or collective rooming, on the request of pasteurized human milk. Method: an exploratory and a descriptive research, with a quantitative approach, developed in a maternity school, located in Natal/Rio Grande do Norte, Brazil. The data were collected between May and August 2010, along with 55 professionals, using questionnaires and information obtained were treated with descriptive statistics. Results: the majority of the subjects consisted of women, nursing techniques, aged between 30 and 49 . On the need of the infant receiving human milk pasteurized, there is ignorance on the part of professionals, who reported being necessary to request this food for babies of women with little or no colostrum. Conclusion: it is imperative to promote permanent strategies for continuing education among professionals about the functioning of the Human Milk Bank, especially on the distribution of pasteurized human milk. Descriptors: Milk banks, Health personnel, Maternity.

Objetivo: verificar o conhecimento da equipe de saúde que atua em Unidade de Terapia Intensiva neonatal e/ou alojamento conjunto, quanto à solicitação do leite humano pasteurizado. Método: pesquisa exploratória e descritiva, com abordagem quantitativa, desenvolvida em uma maternidade escola, situada em Natal/RN, Brasil. A coleta de dados ocorreu entre maio e agosto de 2010, junto a 55 profissionais, por meio de questionários e as informações obtidas foram tratadas com a estatística descritiva. Resultados: a maioria dos sujeitos constituiu-se de mulheres, técnicas de enfermagem, com idade entre 30 e 49 anos. Sobre a necessidade de o lactente receber leite humano pasteurizado, verificou-se desconhecimento por parte dos profissionais, os quais referiram ser necessário solicitar este alimento para bebês de mulheres com pouco ou nenhum colostro. Conclusão: faz-se imperativo promover estratégias de educação permanente junto aos profissionais sobre o funcionamento do Banco de Leite Humano, especialmente quanto à distribuição do leite humano pasteurizado. Descritores: Bancos de leite, Profissionais da saúde, Maternidades.

RESUMEN

Objetivo: Evaluar el conocimiento del equipo de salud que trabaja en la unidad neonatal de cuidados intensivos y/o pensión, a petición de la leche humana pasteurizada. Método: investigación exploratorio y descriptivo, con enfoque cuantitativo, realizado en un hospital de maternidad, situado en Natal / Rio Grande do Norte, Brasil. Datos fueron recogidos entre mayo y agosto de 2010, con 55 profesionales, a través de cuestionarios y la información obtenida se trata con estadística descriptiva. Resultados: La mayoría de los sujetos fueron mujeres, técnicas de enfermería, con edades comprendidas entre los 30 y los 49 años. Sobre la necesidad del niño de recibir la leche humana pasteurizada, existió desconocimiento por parte de los profesionales, que reportaron ser necesario solicitar este alimento para los bebés de las mujeres con poco o nada de calostro. Conclusión: Es imperativo promover estrategias para la educación continua junto a los profesionales sobre el funcionamiento del Banco de Leche Humana, en particular la distribución de la leche humana pasteurizada. Descriptores: Bancos de leche, Personal de salud, Maternidades.

${ }^{1} \mathrm{PhD}$ in Nursing. Associate Professor at the Federal University of Rio Grande do Norte. A leader of the research group Nursing Care at Different Life Stages. ${ }^{2}$ Academic of the 9 th semester of Nursing, Federal University of Rio Grande do Norte. Scientific Initiation Scholarship Voluntary ${ }^{3}$ Nurse. MS Student of the Postgraduate Program in Nursing, Federal University of Rio Grande do Norte. Scholarship Student of the Program Scholarship Coordination and Improvement for Higher Education Personnel (CAPES). 4 Academic of the 9th semester of Nursing, Federal University of Rio Grande do Norte. Scientific Initiation Scholarship Voluntary. 5 Nurse Obstetrician. Master in Nursing of the Postgraduate Program in Nursing of the Federal University of Rio Grande do Norte. 


\section{INTRODUCTION}

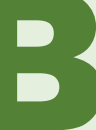

reastfeeding is a biologically determined process which is realized in the social and cultural context of women and family. This act provides many benefits to the child, having highlighted the effectiveness in promoting child growth and development, but also in reducing morbidity and mortality in this population group. Furthermore, this event brings improvements to women's health, which, while breastfeeding, presents a shorter uterine involution, lochia reduction, in addition to acquiring greater protection against breast cancer throughout his life. ${ }^{1}$

Due to the positive effects of breast milk, especially to child health, this food is essential to maintain the infant's daily needs, being the leading choice among both forms of nutrition for newborn (NB), as for premature. ${ }^{2}$

However, there are circumstances in which specific maternal breastfeeding and postpartum woman has restrictions are advised not to breastfeed their child, they are: women infected with Human Immunodeficiency Virus (HIV) or diagnosed with leukemia undergoing chemotherapy or taking medication such as antibiotics and neuroleptics. Moreover, problems regarding the $\mathrm{RN}$ related to prematurity, allergies and gastroenteritis heterologous proteins are also some of the reasons that preclude breastfeeding in the mother's womb. ${ }^{1,3}$

Faced with such environments and recognizing the importance of breast milk in the diet of infants, the professionals who assist both mother and child need to ensure this food otherwise. In this sense, it is necessary to your request to Human Milk Bank (HMB). This consists of a specialized center attached to a hospital for maternal and/or infant, whose charge is to promote, protect and encourage breastfeeding. Moreover, it has the responsibility to perform actions such as collection, selection, classification, processing and quality control of colostrum, transitional milk and mature human milk, to then be distributed by prescribing medical professional or nutritionist. ${ }^{4}$

Specifying the distribution of pasteurized human milk (LHP-in Portuguese), this can be done internally in the hospital which the BLH (Bank of Human Milk - in Portuguese) is linked as well to the demands of other institutions, public or private. However, it is essential that, in both cases, the request LHP follow pre-established criteria and is related to the conditions experienced by the mother and/or newborn. Thus, it is essential to health professionals meet these criteria, avoiding ask routinely and randomly the LHP. 5 For many times, the LHP is requested in circumstances where the mothers are lactating and are able to feed your child, but do not. This fact relates to the cultural conditions that create obstacles in the execution of the act of breastfeeding, as the idea of the existence of weak and insufficient milk. ${ }^{6}$

Therefore, it is necessary that health professionals - especially those working in rooming and Intensive Care Units (ICU) Neonatal - inform women about the benefits of 
breastfeeding, in order to increase the breastfeeding rates and reduce beliefs and taboos wrapped in this practice. Moreover, it is imperative technical expertise of professionals to conduct preliminary examination in postpartum women, in order to verify their conditions breastfeeding or milk. This becomes relevant because knowledge about the actual distribution criteria LHP is essential in maintaining the stock BLH.

Upon the foregoing, questioned: what is the knowledge of the health care team about the need to require the Pasteurized Human Milk for newborn in rooming and Neonatal Intensive Care Unit?

\section{OBJECTIVE}

To check the knowledge of the health care team who works in neonatal ICU and/or rooming, as the request of Human Milk Pasteurized.

\section{METHOD}

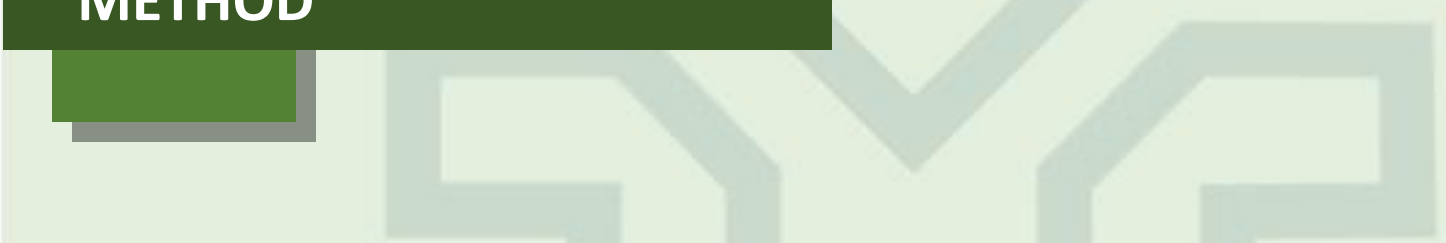

This is an exploratory and descriptive study, with a quantitative approach, developed in a maternity hospital linked to a federal institution, located in Natal/ RN, Brazil.

The study sample consisted of 55 health professionals. Inclusion criteria for this study, workers should act in the NICU rooming and be a pediatrician and/or neonatologist, nurses and nursing technicians. Thus were excluded from the study if they were professional holiday, not included in the above categories are not linked to sectors and NICU rooming or even those whose relationship with that institution was an intern.

The data collection occurred between May and August 2010, the work schedule of the participants. Therefore, it was used as a survey instrument with open and closed questions, related to sociodemographic data of the study population, as well as the specific object of study.

Preceded this step, the consent of the institution where the research was conducted, the approval of the Ethics Committee of Research the Federal University of Rio Grande do Norte, under opinion $n^{\circ} 194 / 09$ and $n^{\circ}$ CAAE 0213.0.051.000.09. Furthermore, it was requested to signing the informed consent by participants, as established by Resolution $196 / 96$ of the National Health Council, in relation to human research. ${ }^{7}$

The data from the questionnaires were processed in accordance with the descriptive statistics presented in the form of table and charts. The analysis and discussion of results were based on the existing literature on breastfeeding and BLH. 


\section{DISCUSSION}

Analyzing the responses contained in the questionnaires regarding sociodemographic data, it was found that among the 55 subjects involved in the study, 52 (95\%) were female. On the age group, 12 (22\%) had professionals aged between 30 and 34 years old and the same number was recorded in the age range 45-49 years old. Please note that only $1(2 \%)$ of the study participants reported being 60 or older. As for the professional category, 29 (53\%) corresponded to the professional nursing staff, 18 (33\%) were nurses, and 8 (14\%) physicians (Table 1).

Table 1 - Distribution of the subjects by gender, age and profession. Natal / RN 2011.

\begin{tabular}{ccc}
\hline Variables & N (55) & $\%$ \\
\hline $\begin{array}{c}\text { Gender } \\
\text { Female } \\
\text { Male }\end{array}$ & 52 & 95 \\
Age & 03 & 5 \\
$20|-| 24$ & 01 & 2 \\
$25|-| 29$ & 03 & 5 \\
$30|-| 34$ & 12 & 22 \\
$35|-| 39$ & 07 & 13 \\
$40|-| 44$ & 07 & 13 \\
$45|-| 49$ & 12 & 22 \\
$50|-| 54$ & 08 & 14 \\
$55|-| 59$ & 04 & 7 \\
60 or older & 01 & 2 \\
Proession & & \\
Nursing technicians & 29 & 53 \\
Nurses & 18 & 33 \\
Physicians & 08 & 14 \\
\hline
\end{tabular}

According to Table 1, it is observed that most of the subjects were inserted between the ages of 30 and 49 years old. This finding agrees with the productive age population, which is considered, in economic terms, individuals whose age is between 15 and 65 years old.

On the presence of the highest number of female professionals, particularly nursing staff, this result was expected. For, from the beginning, this profession is predominantly composed of women. The feminization of nursing is due primarily to the fact that the phenomenon of care be tied to females, because of the socialization of women attributing to them the responsibility for the care and maintenance of life. Although in recent years several changes have occurred in the profession, especially with the rise of the male contingent in nursing teams, is still prevalent in the female field. ${ }^{8-9}$

As regards the number of professionals in the categories studied, we observed a higher number of nursing staff compared to nurses and doctors. This finding is consistent with the reality of hospitals in health, especially when it comes to the nursing staff, which presents subdivision professionals, nurses and technicians, with emphasis on the latter. 
A numerical expression of this category of workers is due to the fact that they are responsible for performing technical activities directly involved in the care of the client, while the nurses develop management actions and specialized care. The sizing and the adequacy of the quantitative and qualitative framework of professional nursing staff are based on the characteristics of the institution/company, the technical and administrative aspects of nursing services offered, as well as the classification system of the patients. Thus, the number of these workers varies according to the hospital sector and the type of assistance offered by him. ${ }^{10}$

To verify the knowledge of professionals about the need to request the LHP, we sought to identify the guidelines offered to women immediately postpartum, which stimulate breastfeeding, in order to avoid unnecessarily LHP request. Thus, the answers given were related to postpartum care, newborn care, and both mother and child (Figure 1).

\begin{tabular}{|l|c|}
\hline \multicolumn{2}{|c|}{ JUSTIFICATIONS } \\
\hline Related to Puerperals & Number of Responses \\
\hline Prevent cracks on the nipples & 08 \\
\hline Stimulate breast milk production & 06 \\
\hline Increase safety for breastfeeding & 05 \\
\hline Prevent breast engorgement & 05 \\
\hline Assist in uterine involution & 05 \\
\hline $\begin{array}{l}\text { Improve understanding of the mother as the handle of } \\
\text { the NB (new born) }\end{array}$ & \\
\hline & \\
\hline Related to NB & 12 \\
\hline Protect the NB of diseases/infections & 05 \\
\hline Composition of human milk & 04 \\
\hline Avoid early weaning & \\
\hline & \\
\hline Related to the Binomial mother and NB & 22 \\
\hline Strengthen mother/child bonding & 11 \\
\hline Promote benefits for mother and baby & 07 \\
\hline Increasing breastfeeding success & \\
\hline
\end{tabular}

Figure 1 - Responses emitted by the subjects on the importance of guiding women in postpartum. Natal / Rio Grande do Norte - 2011.

As seen in Figure 1, the guidelines in the postpartum period that were associated with puerperal were related especially to the prevention of nipple cracks, stimulating the production of breast milk and increased safety for maternal breastfeeding. And to a lesser extent, the professionals mentioned the need to target women as the prevention of breast engorgement, aid in uterine involution and increased understanding of the mother and the handle of the RN.

These results reflect the importance attributed by respondents guidelines able to identify early, mistakes in the practice of breastfeeding. Also show concern for the wellbeing of the infant. In this sense, the answers were highlighted on the prevention of cracked and engorgement. These are the main problems identified during the nursing period, and often those responsible for early weaning. For although such circumstances do not mean impediment to the woman breastfeeding her child, the pain arising from this situation can get her to stop exclusive breastfeeding. ${ }^{11-12}$

In the process of breastfeeding, milk production occurs in response to hormonal stimuli, being involved two hormones, namely: prolactin - responsible for milk production - 
and oxytocin - which promotes milk ejection synthesized. The concentration of these in the blood depends on the stimulation of nerve endings in the nipple-areola complex by breastfed babies. Thus, the milk production of the mother is proportional to the number of feedings. ${ }^{13}$

Thus, according to the answers given by the subjects studied, it is imperative to inform the mother about the physiology of lactation, the prospect of wrapping it in the process, prompting her to breastfeed. Supporting this idea, the authors argue that one of the factors for the success of breastfeeding is in the technical preparation of the progenitor for this practice. ${ }^{14}$ Thus, it is imperative that this preparation occurs during prenatal consultations, and information sent to the woman clearly and free of taxes or judgments. ${ }^{15}$

In the case of the justifications for women issued guidance on how to care for the newborn, they turned to inform it about the protection provided by breastmilk against diseases and infections, as well as information concerning its composition and encourage breastfeeding, with order to avoid early weaning. Concerning the guidelines that have been linked to mother and newborn together, most of the responses reported to be necessary to guide it aiming to strengthen the mother/son, promote benefits for mother and newborn and increase success in breastfeeding.

It is understood these results as arising from the knowledge shown by professionals to refer to the composition of human milk and the importance of breastfeeding. It is known that human milk product is a nutritional compound balanced with all the essential nutrients and bioactive factors. These elements provide protection against infections and allergies due to the stimulation of the immune factors and maturation of organ systems of NB. ${ }^{16}$ Thus, it can be inferred that by informing mothers about the composition of human milk and the importance to the maternal and newborn, healthcare professionals enable women decide more consciously about breastfeed narrowed their children and bond with them.

About the justifications issued by the subject of the importance of guiding the woman questions relating to the mother and newborn, these were mainly related to the strengthening of the bond between them. According to the Ministry of Health a pleasurable and continuing breastfeeding can bring psychological benefits for the child and the mother, given to enable exchange of affection and confidence to ensure safety and NB, as well as promoting achievement of women. ${ }^{1}$

Regarding knowledge of the participants about the need for NB, to receive PHM (pasteurized human milk) in your diet, it was found among the responses of which the request should occur this food, especially for children of mothers with little or no colostrum, followed by cases NB with hemoglucotest (HGT) and low children of HIV-positive mother. Less frequently, this need was identified for children of diabetic mother; newborns whose mothers presented flat or inverted nipples; preterm infants, infants with disabilities in sucking, low-weight newborns, infants and newborns without good grip with some illness diagnosed (Figure 2). 


\begin{tabular}{|l|c|}
\hline \multicolumn{1}{|c|}{ Criteria for receiving PHM } & Number of Responses \\
\hline Mother with little or no colostrum & 33 \\
\hline NB with low HGT & 18 \\
\hline Mother with HIV & 12 \\
\hline NB son of diabetic mother & 9 \\
\hline Plans or inverted nipples & 8 \\
\hline NB premature & 8 \\
\hline NB with disabilities in sucking milk & 8 \\
\hline NB with low weight & 7 \\
\hline NB who cannot breast suck well & 7 \\
\hline NB with diagnosis of illness & 4 \\
\hline
\end{tabular}

Figure 2 - Responses emitted by the subjects on the need of the newborn receiving PHM in your diet. Natal / RN - 2011.

The answers contained in Figure 2 show the fragility of knowledge of the subjects of research purposes. This can be seen since the highest frequency of responses have fallen in the affirmative expressed request this food when the mothers have little or no colostrum. This reality is at odds with the Board Resolution n. 171, of September 4, 2006, which regulates the activities of $\mathrm{HMB}$ and presents a priority in the receipt of milk collected and distributed by BLH, preterm or low birth weight, unable sucking. Besides these, the abovementioned resolution states that infants diagnosed with gastroenteritis, with trophic nutrition, with immunodeficiency or allergic to heterologous proteins also have priority in receiving LHP. ${ }^{17}$

The lack of knowledge about the request LHP presented in this study corroborates evidence of research conducted in the city of Anapolis/Goiás. This identified erroneous prescriptions for the use of LHP, usually associated with nursing mothers with low milk production. $^{2}$ The occurrence of low milk production is common among mothers of premature due to lack of suction breast and stress experienced by the internment of children in NICU. This phenomenon can also be related to errors in the technique of breastfeeding and lack of knowledge of factors involved in lactation, leading to an alleged hypogalactia frame, as in the case of milk letdown late. ${ }^{14}$

As for respondents who reported being necessary to ask for NB with PHM HGT low, these demonstrated some knowledge. Therefore, their responses agreed with reports of the Baby Friendly Hospital Initiative, which considers necessary to use a dietary supplement in cases of hypoglycemia already installed. ${ }^{18}$

Concerning responses regarding the need to use PHM in children of mothers infected with HIV are in line with the recommendations by the Ministry of Health According to the decree $n^{\circ} 2.415$, of December 12, 1996, is inadvisable mothers with HIV breastfeed their children, conduct cross-lactation and/or donate their milk, in order to prevent infection of the newborn. However, it is worth noting the possibility of these babies receiving milk from their own mothers, provided that there is adequate pasteurization of milk. This process is a safe primarily by inactivating, in its entirety, HIV particles in milk when heated at a temperature of $62,5^{\circ} \mathrm{C}$ during the 30 minute interval. ${ }^{19}$

Given the above, it was found that professionals constituent of the sample demonstrated recognizing the importance of guiding women postpartum in order to ensure the continuation of breastfeeding. However, we found some misunderstanding about the need to request the PHM to NB's diet. 


\section{CONCLUSION}

This study enabled us to verify the knowledge of the health care team who works in the NICU rooming and a maternity hospital linked to a federal institution on request PHM. Thus, the subjects demonstrated recognize the importance of guiding women immediately postpartum, with a view to early identification of errors capable of inactivating the practice of breastfeeding. Moreover, the relevance attributed breastfeeding for both mother and child, especially by enabling the strengthening of the bond between them and be a source of benefit to both.

However, it was evident lack of knowledge regarding the need for distribution of PHM, since the answers most frequently were related to the provision of PHM for newborns whose mothers present little or no colostrum. This fact demonstrates the professional disinformation about the physiology of lactation and operation of HMB.

Therefore, it is recognized as essential strategies to promote lifelong learning among professionals involved in the care of postpartum women and newborns, in order to contribute to better targeting of mothers about breastfeeding. Moreover, it is crucial that these workers knowing the operation of the HMB, especially the distribution of PHM therefore the involvement of all enable the equitable provision of this type of milk, but also ensure their stock in HMB. 


\section{REFERENCES}

1. Mistério da Saúde (BR). Saúde da criança: nutrição infantil - aleitamento materno e alimentação complementar. Brasília (DF): Ministério da Saúde; 2009.

2. Silveira MMM, Barbosa NB. Aleitamento materno no município de Anápolis: saberes e práticas na Estratégia Saúde da Família. Rev APS. [periódico online] 2010; [citado em 10 jan 2013]; 13(4):445-55.

Disponível

em: http://www.aps.ufjf.br/index.php/aps/article/viewArticle/928

3. Agência Nacional de Vigilância Sanitária (BR). Banco de leite humano: funcionamento, prevenção e controle de riscos. Brasília (DF): Anvisa; 2008. [citado 15 dez 2012]. Disponível em: http://www.fiocruz.br/redeblh/media/blhanv2008.pdf

4. Ministério da Saúde (BR). Portaria $n^{\circ} 2.193$, de 14 de setembro de 2006. Define a estrutura e a atuação dos Bancos de Leite Humano (BLH). Brasília (DF): Ministério da Saúde; 2006. [citado 10 dez 2012]. Disponível em: http://bvsms.saude.gov.br/bvs/saudelegis/gm/2006/prt2193_14_09_2006.html.

5. Nóbrega EJPB. Ações de profissionais relativas à distribuição de leite humano pasteurizado: uma perspectiva da mudança [dissertação]. Natal (RN): Programa de Pósgraduação em Enfermagem, Universidade Federal do Rio Grande do Norte; 2011.

6. Menezes VA, Granville-Garcia, AF, Silva PM, Silva RB, Falcão AL, Cavalcanti AL. Fatores associados ao desmame precoce no município de São José dos Bezerros/PE. UFES Rev Odontol. [periódico online] 2008; [citado 10 jan 2013]; 10(2):14-21. Disponível em: http://periodicos.ufes.br/RBPS/index

7. Ministério da Saúde (BR). Conselho Nacional da Saúde. Resolução nº 196/96. Normas regulamentadoras de pesquisa envolvendo seres humanos. Brasília (DF); 1996.

8. Lopes MJM, Leal SMC. A feminização persistente na qualificação profissional da enfermagem brasileira. Cadernos Pagu. 2005;1(24):105-25.

9. Campos PFS, Oguisso TA. A Escola de Enfermagem da Universidade de São Paulo e a reconfiguração da identidade profissional da Enfermagem Brasileira. Rev Bras Enferm. 2008; 61(6):892-98.

10. Conselho Federal de Enfermagem. Resolução $n^{\circ} 293$, de 21 de setembro de 2004. Fixa e estabelece parâmetros para o dimensionamento do quadro de profissionais de enfermagem nas unidades assistenciais das instituições de saúde e assemelhados [citado 10 jan 2013]. Disponível em: http://pnass.datasus.gov.br/documentos/normas/122.pdf

11. Parizotto J, Zorzi NT. Aleitamento materno: fatores que levam ao desmame precoce no município de Passo Fundo, RS. O Mundo da Saúde. 2008:32(4):466-74.

12. Gomes LMX, Lopes RA, Carvalho MAF, Barbosa TLA. Difficults faced by mothers to breastfeed her first child. $R$ pesq: cuid fundam Online. [periódico online] 2011; [citado 16 jan 2013]; 3(3):2137-46. Disponível em:

http://www.seer.unirio.br/index.php/cuidadofundamental/article/view/1418/pdf_398 
13. Arantes CS, Montrone AVG, Milioni DB. Concepções e conhecimento sobre amamentação de profissionais da atenção básica à saúde. Rev Eletr Enferm. [periódico online] 2008; [citado jan 2013]; 10(4):933-44. Disponível em: http://www.fen.ufg.br/revista/v10/n4/pdf/v10n4a06.pdf

14. Gaíva MAM, Medeiros LS. Lactação insuficiente: uma proposta de atuação do enfermeiro. Cienc Cuid Saude. 2006; 5(2):255-62.

15. Almeida IS, Ribeiro IB, Rodrigues BMRD. Amamentação para mães primíparas: perspectivas e intencionalidades do enfermeiro ao orientar. Cogitare enferm. [periódico online] 2010; [citado 16 jan 2013]; 15(1):19-25. Disponível em: http://ojs.c3sl.ufpr.br/ojs2/index.php/cogitare/article/view/17139/11282

16. Aprile MM, Feferbaum R, organizadores. Banco de Leite Humano. São Paulo (SP): Atheneu; 2011.

17. Agência Nacional de Vigilância Sanitária (BR). Resolução $n^{\circ} 171$, de 4 de setembro de 2006. Dispõe sobre o regulamento técnico para o funcionamento de Bancos de Leite Humanos [citado 11 jan 2013]. Disponível em: http://www.redeblh.fiocruz.br/media/rdc_171.pdf

18. Organização Mundial da Saúde. Fundo das Nações Unidas para a Infância. Guia de avaliação de Hospital Amigo da Criança. Brasília (DF): Ministério da Saúde; 1999.

19. Ministério da Saúde (BR). Portaria $n^{\circ}$ 2.415, de 12 de dezembro de 1996. Recomendações da Comissão Nacional de AIDS para a prevenção da contaminação pelo HIV, por intermédio do aleitamento materno [citado 11 jan 2013]. Disponível em: http://bvsms.saude.gov.br/bvs/saudelegis/gm/1996/prt2415_12_12_1996.html. 